\title{
ANALISIS POSISI KERANGKA KAPAL TERHADAP KESELAMATAN ALUR PELAYARAN MENGGUNAKAN DATA MULTIBEAM ECHOSOUNDER (Studi Kasus: Alur Pelayaran Barat Surabaya)
}

\author{
Yuwono, Danar Guruh Pratomo, Muhammad Ilham Fahmi Al-Azhar \\ Departemen Teknik Geomatika, Fakultas Teknik Sipil, Lingkungan, dan Kebumian, \\ Institut Teknologi Sepuluh Nopember (ITS) \\ Jl. Arief Rahman Hakim, Surabaya 60111 Indonesia \\ e-mail: yuwono@geodesy.its.ac.id
}

\begin{abstract}
Abstrak
Tingkat kecelakaan transportasi laut di Indonesia terus meningkat dalam kurun waktu tujuh tahun terakhir. Sejak 2010-2016, terdapat total 54 kasus kecelakaan kapal di Indonesia. Untuk wilayah Alur Pelayaran Barat Surabaya sendiri, tercatat ada 10 kerangka kapal yang karam di dasar laut. Keberadaan kerangka kapal tersebut dapat membahayakan keselamatan alur pelayaran serta mengganggu efektivitas kinerja distribusi logistik di Indonesia Timur. Salah satu alat yang dapat digunakan untuk mendeteksi keberadaan kerangka kapal adalah multibeam echosounder, dengan memanfaatkan prinsip kerja gelombang akustik untuk memperoleh data batimetri serta detail morfologi seabed.

Hasil penelitian menunjukkan, kerangka kapal dengan nama "Tongkang Utama 9" ditemukan telah berada di dalam wilayah alur pelayaran. Nilai kedalaman kerangka kapal tersebut masih aman bagi kapal (dengan nilai draft hingga 8,3 meter) yang berlayar di atasnya. Namun, lokasi kerangka kapal tersebut hanya berjarak 10 meter dari as alur pelayaran, sehingga jenis lalu lintas alur pelayaran di wilayah APBS harus mengalami perubahan menjadi sistem rute satu arah demi kepentingan bersama.
\end{abstract}

Kata kunci : Alur Pelayaran Barat Surabaya, Batimetri, Kerangka Kapal, Multibeam Echosounder

\begin{abstract}
The rate of sea transportation accidents in Indonesia are keep increasing in the last seven years. Since 2010-2016, there are 54 cases of accident in Indonesia. In Surabaya West Access Channel alone, 10 ships are reported sink in the bottom of the sea. The existence of those shipwrecks can put the safety of shipping line in danger and also affecting the efectivity of logistic distribution work rate in East Indonesia. One of the instruments which can be used for detecting the shipwreck is multibeam echosounder, applying the principle of underwater accoustic wave propagation to obtain bathymetry data and details of seabed morphology.

The result of this research shows that the location of shipwreck called "Tongkang Utama 9" has been found inside the shipping line area already. Its depth values also considered still safe to get passed by another ships (which has draft values up to 8,3 meters). But, its location only 10 meters away from the axis of the shipping line, so the types of traffic in Surabaya West Access Channel shipping line must be changed into one route for the greater good.
\end{abstract}

Keywords : Bathymetry, Multibeam Echosounder, Shipwreck, Surabaya West Access Channel

\section{PENDAHULUAN}

Berdasarkan Laporan Komisi Nasional Keselamatan Transportasi (KNKT) periode 20102016, kecelakaan transportasi laut di Indonesia pada 2016 merupakan yang tertinggi dalam tujuh tahun terakhir, dengan jumlah 15 kecelakaan atau mengalami kenaikan sebesar 36 persen dari tahun sebelumnya. Untuk wilayah Alur Pelayaran Barat Surabaya (APBS), terdapat 10 kerangka kapal (shipwreck) yang tertinggal di dasar laut akibat kecelakaan transportasi laut (Lampiran Dinas Hidrografi dan Oseanografi (DISHIDROS) 2013 Peta 96B). Kerangka kapal yang tertinggal di dasar laut tersebut menjadi objek yang harus diangkat berdasarkan Peraturan Menteri Perhubungan Republik Indonesia No. 33 Tahun 2016 tentang Salvage dan/atau Pekerjaan Bawah Air agar tidak membahayakan keselamatan alur 
pelayaran. Metode yang sering digunakan untuk menginvestigasi kolom air dan dasar laut secara efisien dan akurat adalah Hidroakustik. Metode Hidroakustik memanfaatkan gelombang suara yang mampu merambat hingga ke dasar laut dan beberapa lapisan di bawahnya, lalu dipantulkan kembali dan diterima sebagai pantulan balik (echo). Instrumen akustik seperti multibeam echosounder biasa digunakan untuk keperluan survei batimetri. Data batimetri dengan cakupan yang luas menghasilkan Digital Elevation Model (DEM) yang dapat menampilkan detail morfologi seabed (Colbo, dkk, 2014)

Dalam beberapa dekade terakhir, data batimetri dengan resolusi spasial dan temporal yang bagus dimanfaatkan untuk keperluan studi oseanografi, seperti: perikanan, ekosistem rumput laut, sedimen tersuspensi, hingga deteksi kerangka kapal. Survei batimetri menggunakan multibeam echosounder memudahkan proses pencarian kerangka kapal dibandingkan dengan metode konvensional, seperti penyelaman yang membutuhkan keahlian khusus serta keterbatasan manusia untuk dapat bertahan di dalam perairan. Namun, perlu adanya studi lebih lanjut untuk melakukan validasi objek kerangka kapal tersebut, meliputi: pengukuran dimensi kapal, material penyusun kapal, kondisi kapal, survei menggunakan nilai frekuensi yang berbeda, serta rekronstru2002)ksi tiga dimensi citra dari side scan sonar.(Kramadibrata, S.,

Penelitian ini bertujuan untuk memperoleh informasi mengenai lokasi keberadaan kerangka kapal di dasar perairan dari hasil pengolahan data multibeam echosounder. Kemudian, dilakukan analisis posisi kerangka kapal terhadap keselamatan alur pelayaran.

\section{METODE}

\section{A. Lokasi Penelitian}

Penelitian ini dilakukan di sekitar area yang diduga terdapat objek kerangka kapal yang berpotensi membahayakan keselamatan alur pelayaran di wilayah APBS - Pelabuhan Tanjung Perak, dengan rincian koordinat sebagai berikut: $6^{\circ} 54^{\prime} 7,20^{\prime \prime}$ LS - 6 $53^{\prime} 34,80^{\prime \prime}$ LS / 112 $43^{\circ} 51,60^{\prime \prime}$ BT - 112 44'13,20" BT. Lokasi APBS dipilih karena merupakan salah satu alur pelayaran penting di Indonesia, berperan sebagai pintu gerbang menuju ke beberapa pelabuhan di daerah
Surabaya dan Gresik, serta muara dari sejumlah aliran sungai besar, seperti: Sungai Kalimas, Kali Lamong dan Bengawan Solo. Keberadaan kerangka kapal tentunya dapat mengganggu keamanan dalam berlayar serta mempengaruhi efektifitas kinerja, kestabilan, dan kelancaran arus logistik di Jawa Timur. Hal ini sangat vital karena berdampak bagi kelancaran logistik bagi kawasan Indonesia Timur.

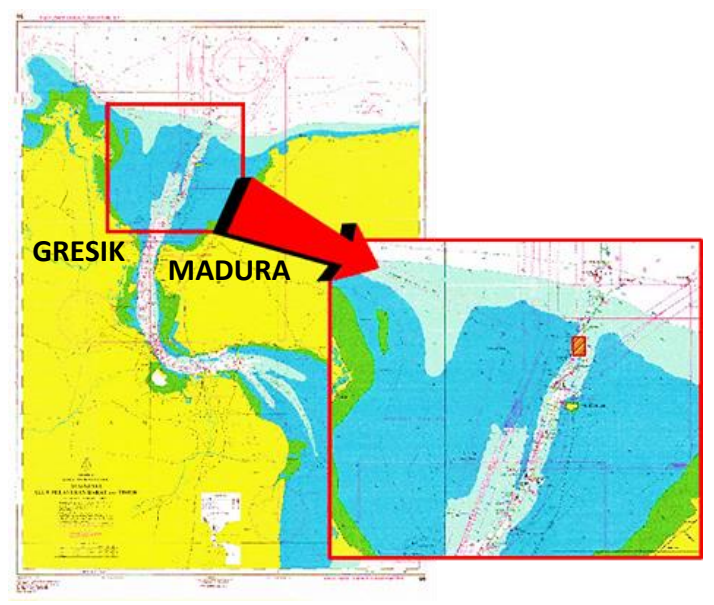

Gambar 1. Lokasi Penelitian

B. Data dan Peralatan

\section{1) Data}

Data-data yang digunakan dalam penelitian ini adalah:

a) Data batimetri (*.pds)

b) Data positioning (koordinat easting-northing, heading kapal, dan tinggi GPS)

c) Data pasang surut air laut (*.tdg)

d) Data profil kecepatan suara (*.svp)

e) Data dimensi kapal

f) Data Peta Laut Indonesia (PLI) wilayah APBS

Data batimetri diakuisisi dengan menggunakan alat multibeam echosounder Teledyne Odom MB2, memiliki frekuensi sebesar $200-460 \mathrm{kHz}$. Untuk data positioning diperoleh dengan alat Global Postioning System (GPS) Trimble $4000^{\circ}$ sebagai sistem penentuan posisi selama survei berlangsung dengan metode kinetik dan sistem Real Time Kinematic (RTK) fix Diferential GPS (DGPS). Kemudian, data pasang surut air laut yang digunakan untuk mengoreksi kedalaman serta memperoleh nilai chart datum berasal dari nilai pengamatan stasiun pasang surut air laut di Pulau Karang Jamuang selama 16 Agustus 2017 per 15 menit, menggunakan tide gauge Thalimedes dan 
palem (rambu) pasang surut air laut. Lalu, untuk data profil kecepatan suara, alat yang digunakan adalah Conductivity, temperature, and depth (CTD) Valeport miniSVS dengan cara dicelupkan pada kedalaman per 0,5 meter dari permukaan air hingga kedalaman 9,5 meter. Data dimensi kerangka kapal yang digunakan untuk keperluan validasi ukuran asli objek kerangka kapal dapat dilihat pada lampiran dari Kementerian Perhubungan (KEMENHUB) Republik Indonesia. Terakhir, basemap yang digunakan adalah Peta Laut Indonesia (PLI) Wilayah Alur Pelayaran Barat dan Timur Surabaya skala $1: 75.000$. Semua data tersebut bersifat sekunder dan diperoleh dari Distrik Navigasi (DISNAV) Kelas I Surabaya.

2) Peralatan

Pada penelitian ini, peralatan yang digunakan terbagi menjadi dua, yaitu perangkat keras (hardware) dan perangkat lunak (software). Untuk perangkat keras, yang dibutuhkan adalah komputer atau laptop. Penulis menggunakan laptop Lenovo ideapad 310 untuk proses pengolahan data, analisis data, hingga pembuatan laporan. Sedangkan untuk perangkat lunak, yang dibutuhkan adalah sistem operasi dan perangkat lunak pengolah data multibeam echosounder. Penulis menggunakan sistem operasi Windows 10 serta perangkat lunak Teledyne PDS.

\section{Metode Pengolahan Data}

Dalam penelitian ini, ada beberapa tahapan yang perlu dilakukan untuk bisa melakukan deteksi kerangka kapal di wilayah alur pelayaran APBS. Data awal yang diperoleh adalah data batimetri (*.pds). Data batimetri tersebut sudah memiliki nilai kedalaman serta data positioning dari GPS (koordinat easting-northing). Langkah awal yang perlu dilakukan adalah kalibrasi patch test untuk menghilangkan kesalahan sistematis alat (transducer) akibat pengaruh pitch, roll, dan yaw. Hal ini dikarenakan kondisi permukaan air yang tidak datar ketika sedang melakukan survei karena adanya pengaruh ombak, sehingga menimbulkan pergerakan pada sumbu-x (roll), sumbu-y (pitch), serta sumbu-z (yaw) kapal terhadap posisi aslinya. Hasil dari proses kalibrasi patch test berupa nilai sudut pergeseran alat dari posisi sumbu awal yang nantinya digunakan untuk mengoreksi data batimetri.

Tahap selanjutnya, dilakukan koreksi kedalaman dengan menambahkan data hasil pengamatan pasang surut air laut serta data hasil survei profil kecepatan suara di bawah air. Untuk data pengamatan pasang surut air laut, nilai koreksi yang ditambahkan harus sudah mengacu pada chart datum, dalam hal ini Lowest Water Level (LWL). Nilai Mean Sea Level (MSL) sebesar 1,21 meter dari 0 rambu, sedangkan nilai Z0 (Jarak dari MSL ke chart datum) sebesar 1,1 meter. Untuk data profil kecepatan suara, koreksi yang diberikan meliputi besar nilai cepat rambat gelombang akustik di bawah air ketika berada pada rentang kedalaman tertentu, dalam hal ini besa cepat rambat gelombang suara secara konstan berada pada kisaran angka $1525 \mathrm{~m} / \mathrm{s}$. Kedua proses di atas sangat krusial untuk bisa memperoleh nilai kedalaman yang sesungguhnya.

Setelah melalui rangkaian tahapan koreksi di atas, nilai kedalaman pada data batimetri sudah bisa dianggap benar dan bisa mulai dilakukan proses penggambaran grid model batimetri multibeam echosounder. Namun, grid model batimetri multibeam echosounder yang dihasilkan masih belum lepas dari pengaruh noise serta memiliki beberapa titik yang tidak memiliki data kedalaman akibat data yang tidak terekam sewaktu survei. Hal ini bisa diatasi dengan melakukan proses filtering untuk menghilangkan noise serta melakukan proses interpolasi sirkular pada titik yang bernilai kosong tersebut.

\section{HASIL DAN PEMBAHASAN}

A. Deteksi Kerangka Kapal pada Grid Model Batimetri Multibeam Echosounder

Pada grid model batimetri multibeam echosounder, posisi horizontal kerangka kapal Tongkang Utama 9 disajikan dengan sistem koordinat Universal Transverse Mercator (UTM) yang terletak di zona $49 \mathrm{~S}$ dan sistem koordinat geografis. Untuk posisi vertikal kerangka kapal Tongkang Utama 9, nilai kedalaman (Z) sudah berdasarkan chart datum Lowest Water Level (LWL), serta mengacu pada datum World Geodetic System 1984 (WGS 84). 


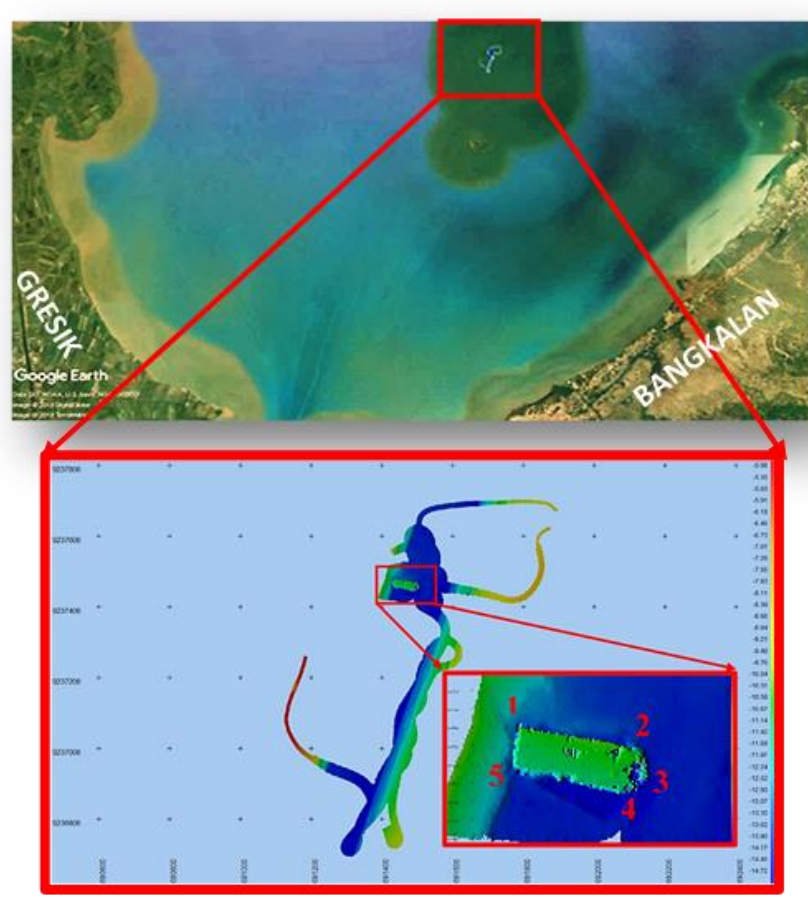

Gambar 2. Identifikasi Objek Kerangka Kapal pada Grid Model Batimetri Multibeam Echosounder

Dengan rincian koordinat kerangka kapal sebagai berikut:

Tabel 1. Koordinat Kerangka Kapal Tongkang Utama 9

\begin{tabular}{c|c|c}
\hline \multirow{4}{*}{1} & $\mathrm{X}$ & 691435,80 meter \\
\cline { 2 - 3 } & $\mathrm{Y}$ & 9237479,40 meter \\
\cline { 2 - 3 } & Lintang & $6^{\circ} 53^{\prime} 43,024^{\prime \prime} \mathrm{LS}$ \\
\cline { 2 - 3 } & Bujur & $112^{\circ} 43^{\prime} 57,277^{\prime \prime} \mathrm{BT}$ \\
\cline { 2 - 3 } & $\mathrm{Z}$ & $-11,01$ meter \\
\hline \multirow{4}{*}{2} & $\mathrm{X}$ & 691499,60 meter \\
\cline { 2 - 3 } & $\mathrm{Y}$ & 9237466,40 meter \\
\cline { 2 - 3 } & Lintang & $6^{\circ} 53^{\prime} 43,442^{\prime \prime} \mathrm{LS}$ \\
\cline { 2 - 3 } & Bujur & $112^{\circ} 43^{\prime} 59,356^{\prime \prime} \mathrm{BT}$ \\
\cline { 2 - 3 } 3 & $\mathrm{Z}$ & $-11,05$ meter \\
\hline \multirow{4}{*}{3} & $\mathrm{X}$ & 691503,70 meter \\
\cline { 2 - 3 } & $\mathrm{Y}$ & 9237453,40 meter \\
\cline { 2 - 3 } & Lintang & $6^{\circ} 53^{\prime} 43,866^{\prime \prime} \mathrm{LS}$ \\
\cline { 2 - 3 } & Bujur & $112^{\circ} 43^{\prime} 59,493^{\prime \prime} \mathrm{BT}$ \\
\hline \multirow{4}{*}{4} & $-12,17$ meter \\
\hline & $\mathrm{Z}$ & 691495,50 meter \\
\cline { 2 - 3 } & $\mathrm{Y}$ & 9237446,50 meter \\
\cline { 2 - 3 } & Lintang & $6^{\circ} 53^{\prime} 44,090^{\prime \prime} \mathrm{LS}$ \\
\hline & Bujur & $112^{\circ} 43^{\prime} 59,227^{\prime \prime} \mathrm{BT}$ \\
\hline & $\mathrm{Z}$ & $-11,79$ meter \\
\hline
\end{tabular}

Ditinjau berdasarkan posisi terakhir ketika kapal Tongkang Utam 9 masih terlihat mengapung di permukaan dan belum tenggelam seutuhnya (estimasi koordinat $6^{\circ} 53^{\prime} 30.00^{\prime \prime} \mathrm{LS}-112^{\circ} 43^{\prime} 44.00^{\prime \prime}$ BT), maka bisa dipastikan bahwa kerangka kapal Tongkang Utama 9 mengalami pergeseran terhadap posisi awal sebesar 633,67 meter ke arah tenggara.

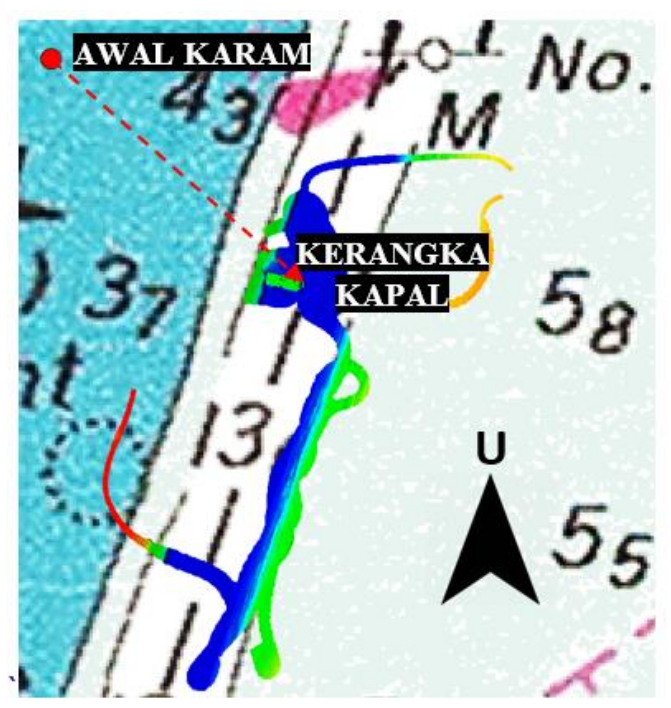

Gambar 3. Perpindahan Posisi Awal Karam dengan Posisi Kerangka Kapal

Berdasarkan proses identifikasi objek kerangka kapal pada grid model batimetri multibeam echosounder, bentuk objek kerangka kapal yang ditemukan nampak seperti bangun datar dua dimensi persegi panjang sederhana dengan tingkat detail dan kompleksitas yang rendah. Hal ini bisa dikatakan wajar mengingat objek kerangka kapal tersebut merupakan jenis "Tongkang" alias kapal angkut, yang kondisi aslinya memang demikian. Kapal Tongkang atau bisa juga disebut sebagai Kapal Ponton adalah jenis kapal yang digunakan untuk membawa kargo. Bentuknya memang sengaja dibuat datar pada bagian lambung layaknya rakit, agar kapasitas angkut argo meningkat. Jenis kapal ini tidak bisa bekerja secara independen, perlu ada Kapal Tunda yang menariknya. Pada tampilan 3D grid model batimetri multibeam echosounder, objek kerangka kapal juga nampak tidak tertutup sempurna (berlubang) seperti yang ditampilkan pada Gambar 4. Lubang tersebut merupakan bekas crane kapal yang telah diambil ketika kapal masih tenggelam sebagian. Tujuannya agar mengurangi tingkat risiko 
bahaya di alur pelayaran serta memudahkan proses pengangkatan kerangka kapal nantinya.
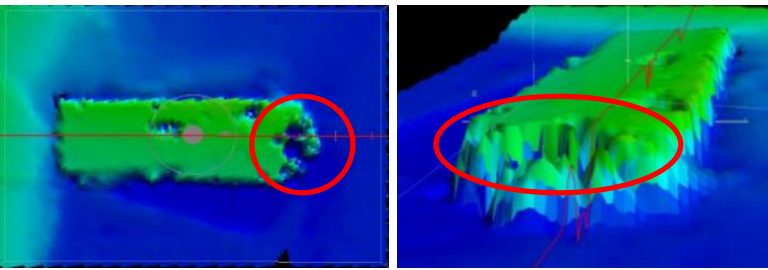

Gambar 4. Model 3D Kerangka Kapal

B. Validasi Dimensi Kerangka Kapal pada Grid Model Batimetri Multibeam Echosounder

Ukuran objek kerangka kapal Tongkang Utama 9 pada grid model batimetri multibeam echosounder dapat divalidasi dengan menggunakan data dimensi kapal Tongkang Utama 9 yang terdaftar di Surat Laut Kementerian Perhubungan (KEMENHUB) Republik Indonesia.

Tabel 2. Dimensi Kapal Tongkang Utama 9

\begin{tabular}{c|c|c}
\hline Panjang $(\mathrm{m})$ & Lebar $(\mathrm{m})$ & Tinggi $(\mathrm{m})$ \\
\hline 70,23 & 24,38 & 4,27 \\
\hline
\end{tabular}

Setelah dilakukan proses identifikasi objek kerangka kapal, dimensi kerangka kapal Tongkang Utama 9 pada grid model batimetri multibeam echosounder bisa dikatakan memiliki kecocokan dengan data dimensi kapal Tongkang Utama 9 milik KEMENHUB sebelum terjadinya kecelakaan, seperti yang tertera pada Gambar 5. dan Gambar 6. di bawah ini:

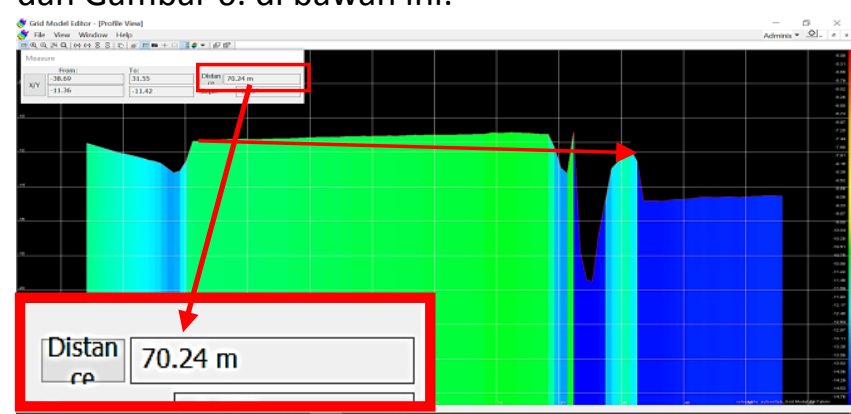

Gambar 5. Profil Memanjang Kerangka Kapal

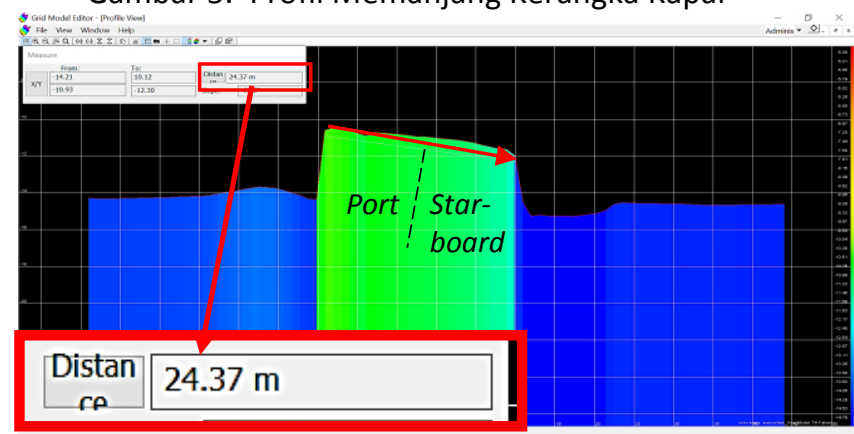

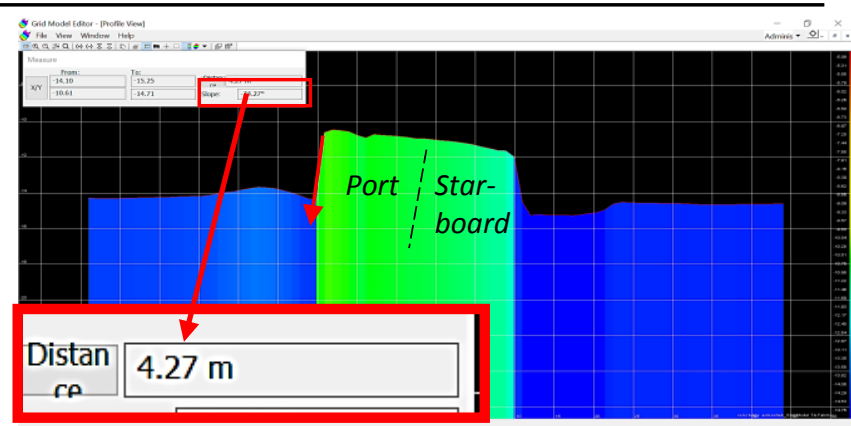

Gambar 6. Profil Melintang Kerangka Kapal

C. Kondisi Kerangka Kapal pada Grid Model Batimetri Multibeam Echosounder

Lebih lanjut, melalui Gambar 2., Gambar 5., dan Gambar 6., penulis bisa memperkirakan besar sudut kemiringan kerangka kapal melalui perhitungan arc tan

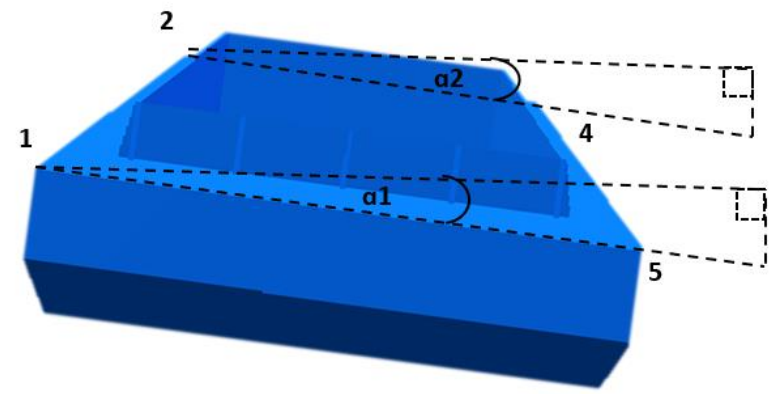

Gambar 7. Ilustrasi Besar Sudut Kemiringan Kerangka Kapal pada Profil Melintang (www. thingiverse.com 2017)

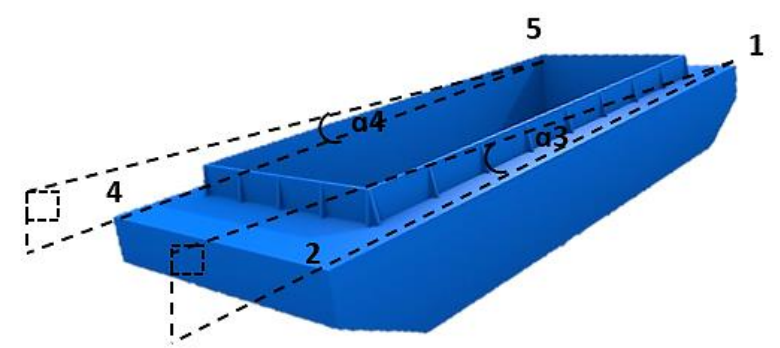

Gambar 8. Ilustrasi Besar Sudut Kemiringan Kerangka Kapal pada Profil Memanjang (www.thingiverse.com 2017)

Jika dilihat secara sekilas dari tampilan profil melintang kerangka kapal pada Gambar 6., kondisi kerangka kapal Tongkang Utama 9 nampak cenderung miring ke bagian starboard kapal (sisi sebelah kanan kapal, dilihat dari belakang). Setelah dilakukan perhitungan arc tan, diperkirakan besar sudut kemiringan kerangka kapal ( $a 1-a 2$ ) antara $1,80^{\circ}-2,08^{\circ}$. 
Sedangkan pada profil memanjang kerangka kapal pada Gambar 5., kondisi kerangka kapal Tongkang Utama 9 nampak cenderung menjorok ke arah dalam mulai dari bagian ujung belakang kapal hingga ke bagian ujung depan kapal. Setelah dilakukan perhitungan arc tan, diperkirakan besar sudut kemiringan kerangka kapal (a3-a4) antara $0,03^{\circ}-0,11^{\circ}$.

\section{Posisi Kerangka Kapal Terhadap Keselamatan Alur Pelayaran}

Untuk verifikasi posisi kerangka kapal Tongkang Utama 9 terhadap alur pelayaran, maka grid model batimetri multibeam echosounder dapat ditampalkan dengan Peta Laut Indonesia (PLI) Wilayah Alur Pelayaran Barat dan Timur Surabaya Skala $1: 75.000$ seperti pada Gambar 9. Ditinjau dari posisinya, bisa dipastikan bahwa lokasi kerangka kapal Tongkang Utama 9 telah memasuki wilayah alur pelayaran di APBS dan berada di bagian tengah salah satu rute alur pelayaran dengan arah melintang.

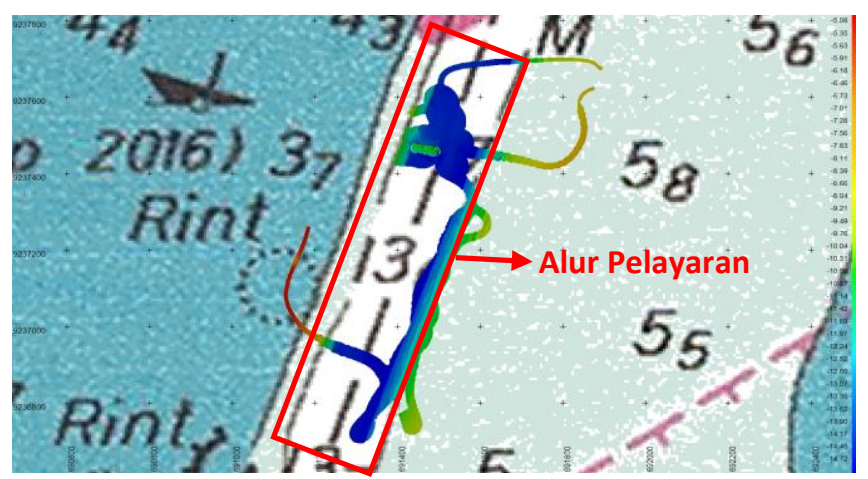

Gambar 9. Posisi Kerangka Kapal Terhadap Alur Pelayaran

Dari data kedalaman grid model batimetri multibeam echosounder, sisa jarak aman antara lunas kapal yang melintasi alur pelayaran di wilayah APBS hingga ke dasar laut bisa dihitung. Dalam hal ini, digunakan nilai kedalaman kerangka kapal Tongkang Utama 9 sebagai acuan pengganti seabed untuk perhitungan nilai under keel clearances (UKC). Penentuan nilai UKC merupakan salah satu faktor penting bagi keselamatan dan efisiensi pelayaran. Adapun kapal (vessel) modern seperti sekarang rata-rata memiliki ukuran yang besar sehingga tidak bisa memasuki wilayah pelabuhan kecuali jika mendekati waktu permukaan air laut mulai pasang. Oleh karena itu, penentuan nilai UKC yang tidak akurat dapat menimbulkan dampak buruk terhadap keselamatan alur pelayaran serta kerugian secara ekonomi. Nilai UKC (Parker dan Huff, 1998) pada Gambar 10. dapat diketahui melalui persamaan (1) berikut:

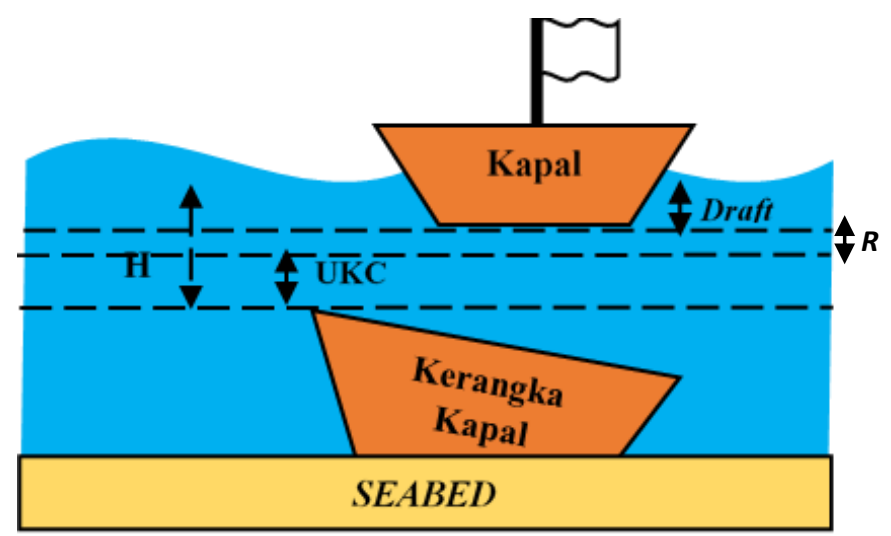

Gambar 10. Under Keel Clearances

$$
\mathrm{UKC}=\mathrm{H}-\text { Draft }-\mathrm{R}
$$

Dimana:

UKC : Under Keel Clearances (m)

$\mathrm{H} \quad$ : Kedalaman kerangka kapal (m)

Draft : Bagian kapal yang tercelup ke air, diasumsikan dengan nilai draft kapal terbesar $(\mathrm{m})$

R : Ruang bebas bersih $10 \%$ dari draft kapal (m)

Maka:

$$
\begin{aligned}
\text { UKC } & =11,01-8,30-(10 \% \times 8,30) \\
& =1,88 \text { meter }
\end{aligned}
$$

Dari hasil perhitungan tersebut, diketahui bahwa nilai UKC sebesar 1,88 meter. Nilai draft pada perhitungan di atas merupakan milik salah satu kapal dengan nilai draft terbesar yang melintasi alur pelayaran di wilayah APBS, yaitu Genting Dream Cruise dengan nilai draft sebesar 8,30 meter serta lebar sebesar 39,70 meter. Nilai kedalaman wilayah perairan minimal yang dibutuhkan oleh Genting Dream Cruise untuk bisa dikatakan aman dalam berlayar dapat dicari melalui rumus (2) di bawah ini:

$$
H=d+G+R+P
$$

Dimana: 


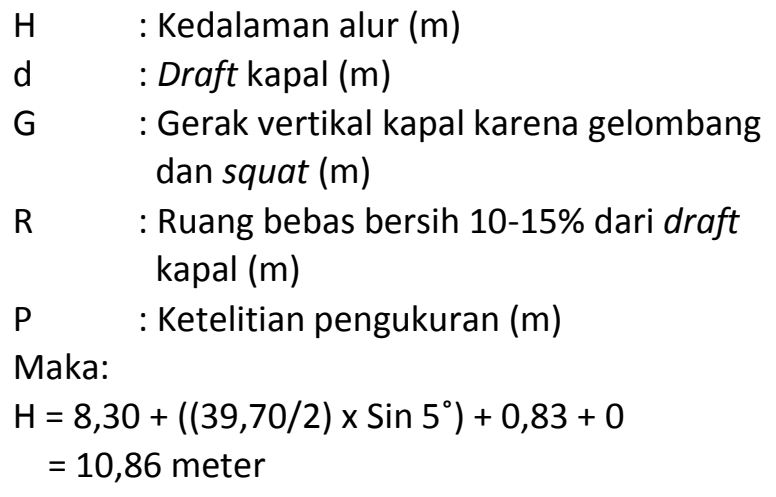

Nilai kedalaman pada lokasi kerangka kapal termasuk masih aman untuk dilewati Genting Dream Cruise. Sedangkan untuk nilai UKC, kapal dilarang memasuki alur pelayaran dengan nilai UKC kurang dari 10\% draft [11]. Dalam hal ini, nilai UKC Genting Dream Cruise juga masih memenuhi syarat $(10 \%$ draft $=0,83$ meter $)$. Dengan demikian, walaupun masih ada sisa jarak aman bagi kapal dengan nilai draft hingga 8,30 meter untuk berlayar tetapi keberadaan kerangka kapal Tongkang Utama 9 di wilayah APBS tetap dikatakan cukup berbahaya bagi keselamatan alur pelayaran (area to be avoided) sehingga tidak boleh ada aktivitas pelayaran di atas lokasi kerangka kapal demi jaminan keamanan serta kondisi di bawah perairan yang tidak bisa kita monitoring setiap saat.

Untuk mengetahui jarak kerangka kapal terhadap as alur pelayaran, diperlukan koordinat fix alur pelayaran di wilayah APBS, seperti yang tercantum pada Tabel 2. dan ilustrasi pada Gambar 8. di bawah ini:

Tabel 2. Sampel Koordinat Alur Pelayaran di Wilayah APBS

\begin{tabular}{c|c|c}
\hline No. & Latitude & Longitude \\
\hline 1. & $6^{\circ} 53^{\prime} 20,491^{\prime \prime}$ LS & $112^{\circ} 44^{\prime} 5,532^{\prime \prime}$ BT \\
\hline 2. & $6^{\circ} 53^{\prime} 22,127^{\prime \prime}$ LS & $112^{\circ} 44^{\prime} 10,136^{\prime \prime}$ BT \\
\hline 3. & $6^{\circ} 58^{\prime} 10,112^{\prime \prime}$ LS & $112^{\circ} 42^{\prime} 22,446^{\prime \prime}$ BT \\
\hline 4. & $6^{\circ} 58^{\prime} 12,367^{\prime \prime}$ LS & $112^{\circ} 42^{\prime} 28,829^{\prime \prime}$ BT \\
\hline \multicolumn{3}{c}{ Gambar 12. Posisi Kerangka Kapal Terhadap } \\
As Alur Pelayaran
\end{tabular}

Pada Gambar 8., lokasi kerangka kapal Tongkang Utama 9 terletak 10,05 meter dari as alur APBS (L). APBS merupakan alur pelayaran yang menerapkan jenis lalu lintas sistem rute dua arah, dengan lebar total sebesar 150 meter (lihat di Gambar 9., nilai L1 dan L2 masing-masing sebesar 75 meter), maka kita bisa mengetahui lebar sisa alur pelayaran yang berada pada radius aman dari lokasi kerangka kapal dan masih bisa digunakan untuk kegiatan pelayaran ( $\left.L^{\prime}\right)$. Karena $L^{\prime}$ bernilai sebesar 85,05 meter, maka sama artinya dengan lebar APBS sementara yang aman untuk digunakan sebesar 85,05 meter pula.

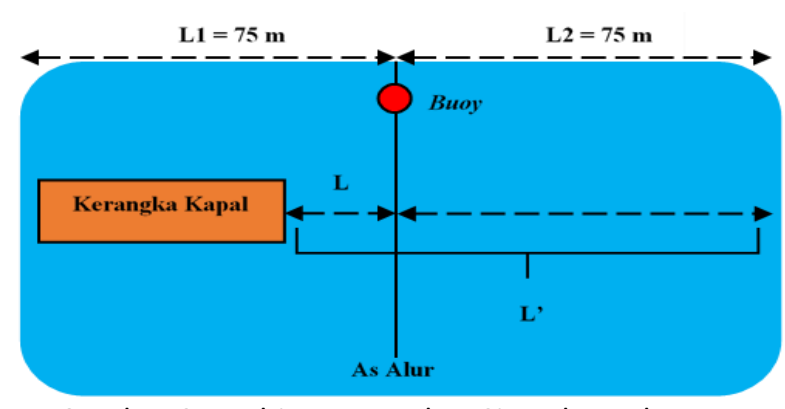

Gambar 9. Perhitungan Lebar Sisa Alur Pelayaran

Lebar kapal lain yang melintasi rute tersebut dijadikan sebagai bahan pertimbangan apakah L' masih memungkinkan atau tidak jika digunakan untuk keperluan alur pelayaran sistem rute dua arah. Mengacu pada rumus lebar alur pelayaran sistem rute dua arah, maka panjang L' sangat jauh dari kata aman untuk keperluan alur pelayaran, seperti perhitungan di bawah ini:

\section{Untuk daerah kapal sering berpapasan:}

$$
L=4 B+30 \text { meter }
$$

Untuk daerah kapal jarang berpapasan:

$$
L=3 B+30 \text { meter }
$$

Dimana:

L : Lebar alur pelayaran $(\mathrm{m})$

B : Lebar kapal (m)

Maka:

Untuk daerah kapal sering berpapasan

$\mathrm{L} \quad=4 \times(30)+30=150$ meter

Untuk daerah kapal jarang berpapasan

L $\quad=3 \times(30)+30=120$ meter

Sedangkan jika mengacu pada rumus lebar alur pelayaran sistem rute satu arah, maka hasilnya juga masih kurang aman namun terbilang cukup mendekati spesifikasi alur pelayaran untuk sistem rute satu arah, seperti perhitungan berikut:

$\mathrm{L}=2 \mathrm{~b}+30$ meter

Dimana:

L $\quad$ : Lebar alur pelayaran (m)

b : : Lebar kapal (m) 
Maka:

$\mathrm{L} \quad=2 \times(30)+30=90$ meter

Adanya faktor pengaman atau pembatas jarak antar kapal seperti $(d, s, f)$ merupakan upaya preventif untuk menghindari terjadinya kecelakaan ketika dua kapal saling berpapasan. Hal ini berkaitan dengan adanya penyimpangan posisi kapal ketika berlayar di laut akibat pengaruh dari arus dan/atau angin. Dampak yang ditimbulkan mengakibatkan kedua kapal yang berpapasan akan saling berjauhan atau justru akan saling berdekatan sehingga dapat menyebabkan terjadinya tubrukan. Dengan demikian, selama kerangka kapal Tongkang Utama 9 masih belum diamankan, maka wilayah APBS di sekitar lokasi kerangka kapal sementara harus mengalami perubahan jenis lalu lintas alur pelayaran dari yang semula sistem rute dua arah kini menjadi sistem rute satu arah, khusus pada daerah yang posisi as alurnya berdekatan dengan kerangka kapal. Estimasi waktu perubahan alur tersebut dapat disesuaikan dengan lamanya waktu pengangkatan kerangka kapal, yaitu paling lambat 30 hari kalender setelah kapal karam. Hal ini dikarenakan kerangka kapal Tongkang Utama 9 termasuk tingkat gangguan I bagi keselamatan alur pelayaran di wilayah APBS. Ditinjau dari lokasinya, kerangka kapal Tongkang Utama 9 berada di perairan pada Daerah Lingkungan Kerja (DLKr) dan Daerah Lingkungan Kepentingan (DLKp).

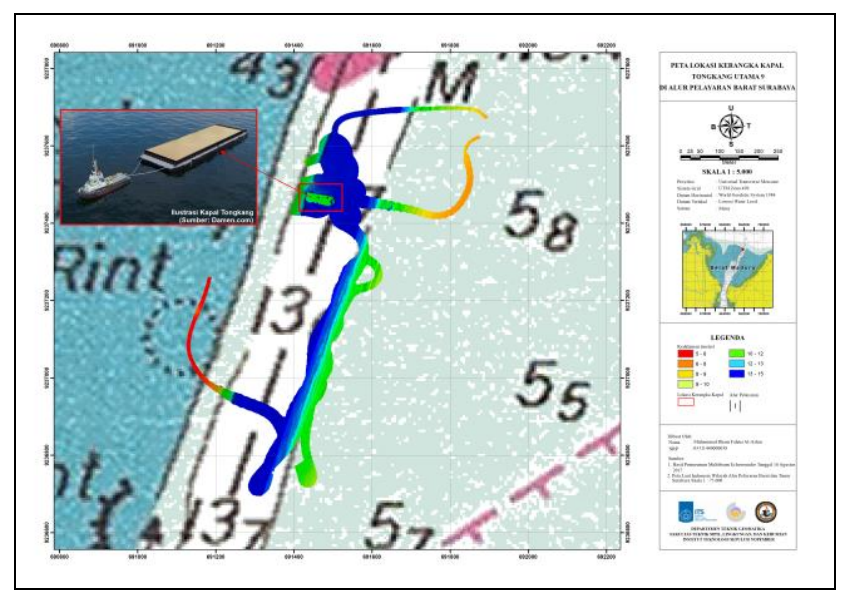

Gambar 10. Peta Lokasi Kerangka Kapal Tongkang Utama 9 di Alur Pelayaran Barat Surabaya Skala 1 : 5.000

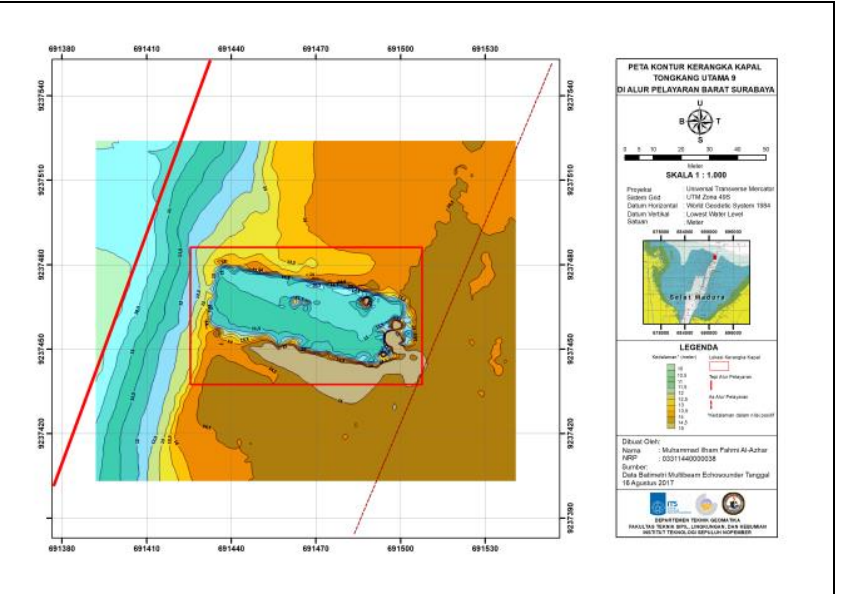

Gambar 11. Peta Kontur Kerangka Kapal Tongkang Utama 9 di Alur Pelayaran Barat Surabaya Skala 1 : 1.000

\section{KESIMPULAN}

Adapun kesimpulan dari penelitian ini adalah sebagai berikut:

- Kerangka kapal ditemukan terletak pada rentang koordinat $6^{\circ} 53^{\prime} 43,024^{\prime \prime}$ LS $6^{\circ} 53^{\prime} 44,133^{\prime \prime}$ LS dan $112^{\circ} 43^{\prime} 57,277^{\prime \prime}$ BT $112^{\circ} 43^{\prime} 59,493^{\prime \prime}$ BT.

- Dari segi lokasi, objek kerangka kapal "Tongkang Utama 9" telah berada di dalam wilayah APBS, dengan posisi melintang terhadap salah satu rute alur pelayaran.

- Kedalaman pada lokasi kerangka kapal masih memiliki nilai UKC yang memenuhi syarat untuk dilewati oleh kapal dengan nilai draft hingga 8,30 meter.

- Walaupun demikian, keberadaan kerangka kapal Tongkang Utama 9 di wilayah APBS dianggap berbahaya bagi keselamatan alur pelayaran (area to be avoided) demi jaminan keamanan serta kondisi di bawah perairan yang tidak bisa kita monitoring setiap saat.

- Jenis lalu lintas di wilayah APBS harus dirubah menjadi sistem rute satu arah dari yang semula menganut sistem rute dua arah, untuk wilayah yang lokasi as alurnya berdekatan dengan kerangka kapal Tongkang Utama 9.

Sedangkan saran yang bisa diberikan untuk pengembangan penelitian ini kedepannya adalah diperlukan adanya data pendukung lain seperti data kolom air ataupun data citra side scan sonar untuk bisa menggali informasi lebih lanjut terkait kondisi kerangka kapal di dasar laut. 


\section{UCAPAN TERIMA KASIH}

Penulis mengucapkan terima kasih kepada pihak Distrik Navigasi (DISNAV) Kelas I Surabaya yang telah membantu terlaksananya penelitian ini, terutama perihal ketersediaan data-data yang diperlukan serta bimbingan selama proses pengolahan data.

\section{DAFTAR PUSTAKA}

Colbo, K., Ross, T., Brown, C., dan Weber, T., 2014, “ $A$ Review of Oceanographic Applications of Water Column Data from Multibeam Echosounders". Estuarine, Coastal, and Shelf Science:1-16.

Kramadibrata, S., 2002, Perencanaan Pelabuhan, ITB, Bandung.Marinelnsight.

https://www.marineinsight.com/types-ofships/different-types-of-barges-used-in-theshipping-world/>. Dikunjungi pada $30 \mathrm{Mei}$ 2018, jam 02.30 WIB.

Parker, B., B., dan Huff, L., C., 1998, “Modern UnderKeel Clearance Management", International Hydrographic Review LXXV:143-165. Jakarta. 